\title{
Learning to live in a greenhouse
}

The dictum about not throwing stones in greenhouses may be generally applicable in the years ahead. Incoherent bad temper is on the increase, while even well-intentioned official committees may make things worse.

THE property correspondent of the British newspaper The Financial Times was quick off the mark last Saturday. "Amid all the talk of the greenhouse effect", he wrote, "there is a particular problem for estate agents [otherwise "realtors"] in low-lying parts of the UK" - that of "allaying fears ... of inundation" among potential house and land purchasers. Noting that much of eastern England is either at or below sea level, he went on to declare that "the risk, in fact, is minimal ... the Dutch long ago showed that modern engineering with sufficient funding is up to the task". It will be interesting to see what they make of that in Bangladesh.

Meanwhile, in Britain and the rest of Europe, the heat seems to be getting to people. Prime Minister Margaret Thatcher's promise that Britain's greenhouse emissions will be no greater in 2005 than in 1990 has been denounced by environmental groups as inadequate. The European Communities have, rather, the same objective for the end of this decade, largely on the strength of a conference in the Netherlands last year that the British government ostentatiously chose not to attend. But there is no formal agreement yet, no mechanism by which European compliance might be achieved and, importantly, no set of yardsticks by which compliance and/or failure to comply might be assessed, let alone sure knowledge of how governments might best comply.

If the excess greenhouse effect proves to be real, that will be bad enough, but the bad temper the prospect seems certain to engender will be something else unwanted. No purpose will be served by a competition between national governments to be first with self-denying regulations on carbon dioxide and other gases - the result would simply be to reduce the pressure on others. The need is for the framework of a convention. Without that, self-denial is like unilateral disarmament.

Nor does it help that well-intentioned bodies such as the Response Strategies Working Group of the UN Intergovernmental Panel on Climate Change put out such woolly statements as its first draft summary report (prudently labelled "Do not quote"). The group correctly concludes that a convention is the central need, and similarly recognizes that the disparity between rich and poor countries is inseparable from the greenhouse problem. But then, perversely, it argues that the intellectual property rights of companies from developed countries should be disposed of as the recipients of technology think fit, apparently ignorant of the importance of just that issue in the UN-sponsored negotiations now under way in the General Agreement on Tariffs and Trade (GATT). It is to be hoped that the working group will have done better by November.

\section{Who makes mistakes?}

The mistakes that researchers make are dwarfed by the mistakes of other professionals, for which we pay.

MisTAKES will happen, but some have greater consequences than others. That is worth bearing in mind when the research profession has often been criticized for the appearance of erroneous research reports in the literature. That is why researchers and their critics may be respectively heartened and chastened by some of the spectacular mistakes that have recently occurred in other professions, notably in accountancy and the law. The difference is that when research reports are in error, it is science that suffers; when accountants or lawyers make mistakes, the costs are met by the rest of us.

Last week, the British banking system put an end to a company called B\&C (for 'British and Commonwealth'), one of the stockmarket successes of the 1980s, which had made the mistake of paying, 18 months ago, roughly $£ 500$ million for a company called Atlantic, whose business of leasing computers had apparently been sustained by its practice of defining future obligations as current profits. When the truth began to trickle out, two months ago, $B \& C$ felt obliged to 'recapitalize' Atlantic to the tune of what it had paid for ownership in the first place, which turned out to be not very different from the net worth of the collection of secondary banks and financial services companies which were the mainstay of its business. It is not surprising that B\&C's creditors decided last week that the company was not merely skating on thin ice, but on liquid water, and pulled the plug. One irony, for those who hold that the future lies in the creative marriage of accountancy and technology, is that $\mathrm{B} \& \mathrm{C}$ happened by accident to have acquired a half share in the biotechnology company Celltech, at what was believed in 1980 to be the cutting edge of high technology, but which is now embarrassed by the prospect of a firesale of its shares.

The case (again British) of the electronics company 